\title{
Why Do Immigration Policies Differ Between Japan and Korea*
}

\author{
Kan Kimura ${ }^{a}$
}

\begin{abstract}
Foreign immigrants to South Korea are transforming the demographic map of the nation. Survey findings have revealed that the rapid influx of foreigners into South Korea since the year of 2000 has brought about a population increase that has surpassed initial government predictions. In contrast, Japan continues to restrict foreign nationals, in spite of sharp decreasing of national population. But why did such a difference in the respective policies of Japan and South Korea regarding foreign workers and immigration, and citizenship, suddenly come into existence after the year of 2000? This paper addresses this single question, and answers to the question that the differences of political opportunity structures around immigration policies in these two countries matter. Firstly, in Japan, the business sectors which want to have more immigrants have difficulties in reestablishing the strong relations with ruling parties but South Korean business still keeps the smooth relations with conservative governments. Secondly, Japanese labor unions regard immigrants as a serious threat against their members' jobs, but immigrant issues are understood as one of the human rights issues against which unions have to work. Thirdly, anti-immigrants groups in Japan are given chances to bring their message through traditional media such as TVs, but the doors of traditional media are closed for the groups in South Korea.
\end{abstract}

\section{Keywords}

Japan, South Korea, immigration, nationalism

Over the past 15 years, South Korea's immigration policy has continued to undergo massive transformation. South Korea was once recognized as one of Asia's top emigration countries. At its peak, South Korea was losing over 40,000 people each year. During the same period, Japan and South Korea were notorious for their rigid oversight of foreign nationals. Prior to the early 1980s, the acquisition of not only permanent residency but also naturalization was difficult for foreign residents. As a result, from its perspective as a nation with regard to its place within international population migration, South Korea was experiencing a massive emigration surplus.

Beginning in the late 1980 s, the migratory trends for foreign workers began a slow shift due to swift economic growth, an accompanying improvement in the living standards, and the popularization of higher education. This confluence of changes brought about an increase of hiring in fields concentrated within secondary industries. Another result was that among young employees, there was disdain for so-called "3D workplaces" those, which are dangerous, difficult, and dirty. Without local workers to fill these jobs, there

aKobe University, Kobe, Japan

\section{Correspondent Author:}

Kan Kimura, Graduate School of International Cooperation Studies, Kobe University, 2-1 Rokkodai, Nada, Kobe, 657-8501, Japan 
was an increase of foreign workers coming into South Korea during this period for these unwanted jobs. Finally, by the 1990s, the South Korean administration began to work on creating a system for bringing in unskilled foreign workers, and thereafter, the "industrial trainee system" was created.

South Korea's acceptance of foreign workers, during this juncture, temporarily begins to proceed toward expansion. However, in this paper, the author wants to stress that up to this point, South Korea's immigration policy was oriented primarily toward containment. During this time, South Korea was acutely aware of the policies of its neighbor Japan, which was similarly beginning to accept foreign workers in a limited capacity. In particular, the form of South Korea's foreign labor policy, the limited acceptance of foreign workers under the euphemism of "trainees", and imposing ineligibility to overstay their "training period" was clearly an emulation of the Japanese system. South Korea was modeling its early policies after Japan's. This means that, to an extent, South Korea's immigration policy was very similar to that of Japan ${ }^{1}$.

However, this is the point at which the policies of the two countries diverge and Japan and Korea's respective immigration policies begin to show significant differences. Since the year 2000, Japan has essentially maintained its traditionally restrictive policies toward foreign workers, and has been silent on a large number of issues, such as extending the vote to foreign nationals, which at the time almost appeared as if it would be realized. In contrast, from the year 2000, South Korea took a directional shift and began to proactively accept foreign workers and made significant progress toward improving their treatment.

Today, the former South Korean "industrial trainee system" has become the "employment permit system", and it has become accepted as a matter of course for foreign workers to be hired as full-time employees. Furthermore, where previously provisions for permanent residence were non-existent, now provisions for permanent residence have been created; and those who are granted permanent residency are also given the right to vote. And that is not all. Along with these changes, the South Korean government, which like Japan's, has kept with its traditional stance on conferring nationality according to jus sanguinus (i.e., hereditary lineage); therefore, it obstinately rejected dual citizenship for immigrant workers and has even reversed some of its policies on nationality. In short, South Korea now expressly allows dual citizenship to individuals within certain defined categories, including highly accomplished foreigners, former Koreans who were adopted internationally as children and now hold foreign citizenship, and elderly Koreans living abroad who have returned to South Korea at the age of 65 or older. Moreover, it has expanded the range of those for whom dual citizenship is admitted by default. For example, individuals with multiple nationalities up to the age of 22, even when they do not choose only one, they are now able to retain their foreign citizenship as long as they vow not to exercise it in South Korea (Fujiwara 2010).

This paper addresses the single question of why such a difference in the respective policies of Japan and South Korea regarding foreign workers and immigration, and citizenship, suddenly came into existence after 2000. Why did Japan and South Korea, which for all intents and purposes had been charting the same course until the 1990s, diverge so completely? It is to this question above all others that the author has devoted in this paper.

This study analyzes the problem in the following steps:

First, the author undertakes a general analysis of Japan's policies regarding the acceptance of foreign workers, extension of the voting franchise to foreign nationals, and immigration and citizenship. This analysis includes an explanation of why Japan's further acceptance of foreign workers and its improvements 
in the treatment of foreign nationals have stalled.

Second, using Japanese discourses, the author offers a theoretical analysis of the functions played by their constituent elements in the acceptance of foreign workers and the treatment of foreign nationals, offering a framework to support the analysis.

Third, the author tests the adequacy of the theoretical framework by using it as a comparison through which South Korea's existing policies for foreign workers and immigration are analyzed.

Finally, through a re-analysis of the findings derived from the author's framework, he clarifies the factors that have brought about the differences in the respective policies of Japan and South Korea regarding foreign workers and immigration.

\section{DISCOURSES ON FOREIGN WORKERS IN JAPAN}

The author begins by examining why Japan takes a less proactive stance on the acceptance of foreign labor. Evidence of their position can be found in the Cabinet's 2004 "Public Opinion Poll on the Acceptance of Foreign Workers" [Naikakufu Daijin Kanbō Seifu Kōhōshitsu (Cabinet Secretariat, Cabinet Public Relations Office) 2004]. This poll undertook a general study into the question of the acceptance of foreign labor. One of its questionnaire items asked for "Reasons for Denying Unskilled Workers". Basically, it divided foreign labor into two categories, "those who have specialist training, capabilities, or knowledge" (skilled workers) and "unskilled workers", and asked people, who held negative opinions about accepting unskilled foreign workers, their reasons for having such sentiments. We must take care to note that these opinions are limited to people who do not agree with the overall acceptance of foreign nationals, and are negatively biased toward accepting foreign labor. We must also note that some individuals might have entered multiple answers simultaneously.

The questionnaire results are listed in Table 1. An incredible number of respondents cited "the possibility of the deterioration of public order" as the reason they opposed foreign workers. Basically, this means that, at least in 2004, a large majority of those who opposed the admission of unskilled workers were concerned that such acceptance could lead to the deterioration of public order.

Another interesting observation that we must keep in mind was that over $40 \%$ people feared that the acceptance of unskilled workers would heighten social unrest in the community. Their fear is also connected to concern over rising unemployment rates among the Japanese. In comparison, a low number of respondents offered economic reasons such as burdening the cost of social security as the reason they opposed the influx of unskilled foreign workers. What can be gleaned from the data is that the reasons underlying the refusal to accept unskilled workers are concerns that there would be deterioration of public order and the social environment, and unemployment would rise even faster.

Another interesting point illustrated by the data is the low number of respondents who cited a systematic or societal lack of preparedness on the Japanese side owing to their "Reasons for Denying Unskilled Workers". In other words, people who feel negatively about accepting unskilled foreign workers associate these negative reasons of "not being able to accept foreign workers" to the foreigners, rather than consider insufficiencies within the immigration system in Japan.

This kind of thinking among Japanese people is also demonstrated in another item from the same opinion poll: "Things to Require From Foreign Workers" (see Table 2). What is interesting about the responses to this polling item is that there is an almost complete lack of emphasis on immigrants being economically responsible. What respondents wanted most from foreign workers was proficiency in the Japanese language and a comprehension of Japanese culture. This is a stark difference from many other 
Table 1. Reasons for Denying Unskilled Workers (Japan), Asked to the People Who Answered "Yes" to Accept Skilled Labor but "No" to Accept Unskilled Labor. Multiple Answers

\begin{tabular}{|c|c|c|c|c|c|c|c|c|c|c|c|}
\hline & $\begin{array}{l}\text { Numbers of } \\
\text { persons } \\
\text { answered }\end{array}$ & $\begin{array}{l}\text { The possibility } \\
\text { of the } \\
\text { deterioration of } \\
\text { public order }\end{array}$ & $\begin{array}{l}\text { The possibility } \\
\text { of the } \\
\text { disturbance in } \\
\text { local societies }\end{array}$ & $\begin{array}{l}\text { The possibility } \\
\text { of the increase } \\
\text { of } \\
\text { unemployment } \\
\text { rate among } \\
\text { Japanese } \\
\text { workers, in } \\
\text { recession }\end{array}$ & $\begin{array}{l}\text { No fair to use } \\
\text { foreign labor } \\
\text { for jobs } \\
\text { Japanese do not } \\
\text { want to take }\end{array}$ & $\begin{array}{l}\text { No cultural } \\
\text { preparation to } \\
\text { accept many } \\
\text { foreigners in } \\
\text { Japan }\end{array}$ & $\begin{array}{l}\text { The possibility } \\
\text { of the damage } \\
\text { to labor } \\
\text { conditions of } \\
\text { Japanese } \\
\text { workers }\end{array}$ & $\begin{array}{l}\text { The possibility } \\
\text { of the burden } \\
\text { on systems on } \\
\text { social welfare } \\
\text { and education } \\
\text { in Japan }\end{array}$ & $\begin{array}{l}\text { Other } \\
\text { reasons }\end{array}$ & $\begin{array}{l}\text { Do not } \\
\text { know }\end{array}$ & $\begin{array}{l}\text { Number } \\
\text { of total } \\
\text { answers }\end{array}$ \\
\hline & Persons & $\%$ & $\%$ & $\%$ & $\%$ & $\%$ & $\%$ & $\%$ & $\%$ & $\%$ & $\%$ \\
\hline Total & 537 & 74.1 & 49.3 & 40.8 & 28.3 & 20.7 & 16 & 14.3 & .2 & .6 & 244.3 \\
\hline Men & 259 & 73 & 46.7 & 42.5 & 26.3 & 19.3 & 15.8 & 15.1 & .4 & -0 & 239 \\
\hline Women & 278 & 75.2 & 51.8 & 39.2 & 30.2 & 21.9 & 16.2 & 13.7 & -0 & 1.1 & 249.3 \\
\hline
\end{tabular}

h16-foreignerworker/index.html). 
Table 2. Things to Require From Foreign Workers (Japan)

\begin{tabular}{|c|c|c|c|c|c|c|c|}
\hline & $\begin{array}{l}\text { Numbers of } \\
\text { persons } \\
\text { answered }\end{array}$ & $\begin{array}{l}\text { Japanese } \\
\text { language }\end{array}$ & $\begin{array}{l}\text { Understanding } \\
\text { of Japanese } \\
\text { cultures }\end{array}$ & $\begin{array}{l}\text { Professional } \\
\text { skills }\end{array}$ & $\begin{array}{l}\text { Financial } \\
\text { assets }\end{array}$ & Others & Do not know \\
\hline & Persons & $\%$ & $\%$ & $\%$ & $\%$ & $\%$ & $\%$ \\
\hline Total & 2,075 & 35.2 & 32.7 & 19.7 & 1.3 & 1.7 & 9.3 \\
\hline \multicolumn{8}{|l|}{ Area } \\
\hline Metropolis & 465 & 40.2 & 30.5 & 20 & 1.5 & 1.7 & 6 \\
\hline Tokyo & 132 & 36.4 & 32.6 & 20.5 & 4.5 & 1.5 & 4.5 \\
\hline Designated cities & 333 & 41.7 & 29.7 & 19.8 & .3 & 1.8 & 6.6 \\
\hline Middle cities & 762 & 32.9 & 33.5 & 21.9 & 1.6 & 1.8 & 8.3 \\
\hline Small cities & 400 & 36.8 & 34 & 15.5 & 1.3 & 2 & 10.5 \\
\hline Towns and villages & 448 & 32.4 & 32.6 & 19.2 & .9 & 1.3 & 13.6 \\
\hline \multicolumn{8}{|l|}{ Genders } \\
\hline Men & 970 & 36.2 & 33.1 & 19.4 & .9 & 2.3 & 8.1 \\
\hline Women & 1,105 & 34.3 & 32.4 & 19.9 & 1.7 & 1.3 & 10.4 \\
\hline \multicolumn{8}{|l|}{ Ages } \\
\hline $20-29$ & 206 & 43.7 & 32.5 & 18 & 1.9 & 1 & 2.9 \\
\hline $30-39$ & 323 & 39.3 & 33.1 & 22.6 & 1.2 & .6 & 3.1 \\
\hline $40-49$ & 340 & 30.9 & 40.6 & 19.4 & 1.5 & 4.1 & 3.5 \\
\hline $50-59$ & 410 & 36.3 & 34.1 & 20.2 & 1.2 & 1.5 & 6.6 \\
\hline $60-69$ & 481 & 33.1 & 31 & 19.3 & 1.2 & 1.7 & 13.7 \\
\hline $70-$ & 315 & 31.7 & 24.8 & 17.8 & 1.3 & 1.3 & 23.2 \\
\hline \multicolumn{8}{|l|}{ Occupations } \\
\hline Self-employed & 276 & 38.8 & 31.9 & 16.7 & 1.1 & 1.4 & 10.1 \\
\hline Family workers & 83 & 37.3 & 34.9 & 14.5 & 1.2 & 2.4 & 9.6 \\
\hline Employers & 809 & 34.6 & 36.7 & 21.5 & 1.1 & 1.6 & 4.4 \\
\hline White-collars & 440 & 33.2 & 38.4 & 21.1 & 1.8 & 1.8 & 3.6 \\
\hline Blue-collars & 369 & 36.3 & 34.7 & 22 & .3 & 1.4 & 5.4 \\
\hline Unemployed & 907 & 34.4 & 29.2 & 19.4 & 1.7 & 1.9 & 13.5 \\
\hline Housewives & 540 & 35.6 & 30.2 & 20.7 & 2 & 1.5 & 10 \\
\hline $\begin{array}{l}\text { Other unemployed } \\
\text { persons }\end{array}$ & 367 & 32.7 & 27.8 & 17.4 & 1.1 & 2.5 & 18.5 \\
\hline
\end{tabular}

Note: Source: Naikakufu Daijin Kanbo Seifu Kohoshitsu “Gaikokujin no ukeire ni kansuru yoronchosa 2004”, retrieved May 16, 2013 (http://www8.cao.go.jp/survey/h16/h16-foreignerworker/index.html).

countries, such as America or South Korea, where a capacity for economic independence among immigrants and foreign workers is preferred to social adaptability.

We can interpret these conditions as follows. The single greatest qualm held by many of the Japanese respondents, particularly regarding the acceptance of unskilled workers, is the concern over the deterioration of public security and social order. But the Japanese are unaware that the reasons foreign nationals might bring about the deterioration of public security and social order are economic in nature.

Their image of the deterioration of public security and social order comes not from images of destitute foreigners feeling the pinch of poverty and turning to a life of crime, but rather from foreigners, having nounderstanding of Japanese or of Japanese culture, a "cultural other" with whom they have no means of 
communication. A cultural other behaves as they please, inadvertently trespassing against the social norms that the Japanese hold to be so important. Together with the comparative lack of concerns about an influx of foreigners, resulting in higher rates of unemployment, we can say that the negative image held by the Japanese toward the influx of foreign labor is concentrated on social issues.

Another poll item, "Reasons for Thinking That Illegal Employment Is Bad", yielded similar results. On this item, approximately $20 \%$ of the respondents referred to economic factors, while the majority were concerned about the effects on public order and morality.

This kind of thinking seems to persist even today. In a 2009 "Public Opinion Poll on International Labor Migration", Japanese language ability, understanding of Japanese culture, and understanding of Japanese customs were rated highly as "Things Required From Foreign Workers," along with specialist knowledge and training, while no more than half of the respondents considered "financial assets such as savings, etc." to be important.

It is interesting to note that the negative rationale, regarding the acceptance of foreign workers apparent in these public opinion polls does not necessarily agree with the government opinion. For example, in the Ministry of Health, Labour, and Welfare publication, "Employment Measures for Foreign Workers", the reasons listed for not accepting foreign nationals on an indefinite basis are not concerned with the deterioration of social order, but rather with "competition for and substitution of domestic labor". The government is not the only entity holding this opinion. Concerns for immigrants who are economically insecure are stressed over anxiety for social conformity in discussions among social elites. In "Issues and Directions in Policies for the Acceptance of Foreign Laborers", a report by organizations such as the Japan Economic Research Institute, an organization co-sponsored by Keidanren and the Japan Chamber of Commerce and Industry, economic insecurity was stressed over anxiety for social conformity as a concern regarding the acceptance of foreign workers.

Next, let us examine the argument that foreign laborers must be allowed into the country. On this point, the Cabinet public opinion polls mentioned earlier asked very little. However, the governmental and industry reports have a lot to say about this matter. The Ministry of Health, Labour, and Welfare's "Draft Employment Policy Research Group Report" [Koyō Seisaku Kenkyūkai (Employment Policy Research Group) 2010], for example, openly characterizes "Addressing the Decrease in the Working Population" as motivation to admit foreign labor into the country. The report on "Issues and Directions in Policies for the Acceptance of Foreign Laborers" cited above, in light of the decrease in the working population, cites the argument that "international competition is escalating with the advance of economic globalization". What is accentuated is that it is important to secure "personnel who are familiar with overseas society, culture, economies, and markets, and who are able to play an active part in the field of international business", thus emphasizing the need to bring in foreigners with specialized knowledge.

While government and industry leaders have been advocating for the need to secure human resources through the acceptance of foreign labor, which would bring about the escalation of competition in the labor market, reduction in wages, and increased production efficiencies, none of this has happened. Of course, this assumes that while these would be foreign workers, they would not be illegal immigrants, and since they would be protected by the public minimum wage system, they could not bring labor costs down below a certain level. A more immediate concern for Japan's domestic production, is that, as the number of Japanese workers who spurn employment in menial jobs continues to increase, attention is turning toward securing absolute numbers. 
Therefore, how should the conditions in Japan be interpreted? The next section studies the conditions from a theoretical perspective.

\section{THE UNDERLYING LOGIC OF ANTI-FOREIGNER SENTIMENT}

Below logically organizes the contents mentioned above.

The author has broadly suggested that the arguments against the acceptance of foreign workers into Japan are supported by two types of rationale. First, it is the anxiety that the acceptance of foreign unskilled labor will bring about a collapse of public order and a destabilization of society. Underpinning this is the perception of the destabilizing role played by a "cultural other" who does not understand the Japanese language or Japanese society. Also, hypothetically speaking, if an influx of foreign workers were to cause some crisis in cultural identity, foreigners would not expect it to be addressed through a systematic or societal accommodation on the Japanese side, but rather resolve it themselves; this is because the Japanese society places the entire burden of assimilation on the outsider. Underlying this attitude is a cultural identity and a way of thinking strongly biased toward assimilation that, no matter what systematic or societal preparations are put in place, it inevitably sees the arrival of "the cultural competition" as a source of havoc. Put simply, it holds that the society should be culturally uniform, and that the collapse of homogeneity will undoubtedly be in the people's disadvantage.

The second rationale is held by politicians and the elites who are clearly not concerned with social order or instability, but with economic influence and especially the increase of unemployment. The author thinks it is important that there is a difference in the "problem scenario" perceived by these differing groups. The general populace expresses concern that an influx of foreign workers unfamiliar with the
Japanese language or Japan's culture will be a destabilizing factor, while the elite-societal level holds that social destabilization would result from a rise in unemployment rates brought about by the hypothetical influx of foreign workers.

The author believes that there are underlying social conditions influencing the differences between the opinions of the general-population responders and the elite-population responders and the consistency of the data that can be derived from them. For example, Table 3 shows current trends in crimes committed by foreign nationals as reported by the National Police Agency. Table 4 shows the current registration of foreign workers as published by the Ministry of Health, Labour, and Welfare. By comparing the influx of foreign nationals to the number of crimes attributed to them, it is evident that despite a steady increase in the registration of foreign workers in Japan, foreigner-related crimes continue to decrease. From the data, one can conclude that there is no observable evidence that the influx of foreign workers has brought about deterioration in public order as related to criminal activity. In other words, the argument made by the general-population responders is not directly supported by the data. This is probably why such arguments are difficult to find among discussions among the elite population.

On the other hand, the impact of the influx of foreign workers on rates of unemployment is open to interpretation $^{2}$. What does seem clear is that there has always been the possibility that an influx of unskilled foreign workers could affect a similar demographic of Japanese workers, and that this effect has been partially observed. In particular, the impact on low-income, male workers is pointed to everywhere, and to a certain point, we can understand that this merits attention.

With these differing points of view, what manner of observation framework can be constructed regarding the problem of foreign workers in South Korea? First, how have these two perceptions evolved 
Table 3. Crimes Committed by Foreign Nationals (Japan)

\begin{tabular}{|c|c|c|c|c|c|c|c|c|c|c|c|c|c|c|c|c|c|}
\hline & & 1983 & 1984 & 1985 & 1986 & 1987 & 1988 & 1989 & 1990 & 1991 & 1992 & 1993 & 1994 & 1995 & 1996 & 1997 & 1998 \\
\hline \multirow[t]{2}{*}{ Arrestees } & Cases & 3,550 & 3,956 & 5,207 & 4,583 & 5,252 & 5,237 & 5,963 & 5,765 & 6,345 & 10,244 & 12,153 & 19,671 & 21,574 & 24,374 & 27,414 & 32,033 \\
\hline & Persons & 3,073 & 3,477 & 3,801 & 3,819 & 4,064 & 4,062 & 4,586 & 4,618 & 4,770 & 7,270 & 9,456 & 12,467 & 13,576 & 11,976 & 11,949 & 13,883 \\
\hline \multirow{2}{*}{$\begin{array}{l}\text { Criminal } \\
\text { offenses }\end{array}$} & Cases & 1,187 & 1,269 & 2,340 & 1,725 & 2,537 & 2,567 & 3,906 & 3,572 & 4,064 & 6,990 & 7,457 & 12,771 & 13,321 & 17,213 & 19,513 & 21,670 \\
\hline & Persons & 1,031 & 1,153 & 1,301 & 1,370 & 1,626 & 1,871 & 3,020 & 2,989 & 2,978 & 4,813 & 5,961 & 7,276 & 6,989 & 6,527 & 6,026 & 5,435 \\
\hline \multirow{3}{*}{$\begin{array}{l}\text { Other law } \\
\text { offenses }\end{array}$} & Cases & 2,363 & 2,687 & 2,867 & 2,858 & 2,715 & 2,670 & 2,057 & 2,193 & 2,281 & 3,254 & 4,696 & 6,900 & 8,253 & 7,161 & 7,901 & 10,363 \\
\hline & Persons & 2,042 & 2,324 & 2,500 & 2,449 & 2,438 & 2,191 & 1,566 & 1,629 & 1,792 & 2,457 & 3,495 & 5,191 & 6,587 & 5,449 & 5,923 & 8,448 \\
\hline & & 1999 & 2000 & 2001 & 2002 & 2003 & 2004 & 2005 & 2006 & 2007 & 2008 & 2009 & 2010 & 2011 & 2012 & $\begin{array}{l}\text { Number of } \\
\text { difference } \\
\text { between } \\
2001 \text { and } \\
2012\end{array}$ & $\begin{array}{l}\text { Ratio of } \\
\text { difference } \\
\text { between } \\
2011 \text { and } \\
2012\end{array}$ \\
\hline \multirow[t]{2}{*}{ Arrestees } & Cases & 31,779 & 34,398 & 30,971 & 27,763 & 34,746 & 40,615 & 47,128 & 47,865 & 40,128 & 35,782 & 31,252 & 27,836 & 19,809 & 17,286 & $-2,523$ & $-12.7 \%$ \\
\hline & Persons & 13,418 & 13,436 & 12,711 & 14,660 & 16,212 & 20,007 & 21,842 & 21,178 & 18,872 & 15,914 & 13,885 & 13,257 & 11,858 & 10,061 & $-1,797$ & $-15.2 \%$ \\
\hline $\begin{array}{l}\text { Criminal } \\
\text { offenses }\end{array}$ & Cases & 21,689 & 25,135 & 22,947 & 18,199 & 24,258 & 27,258 & 32,087 & 33,037 & 27,453 & 25,730 & 23,202 & 20,561 & 14,025 & 12,590 & $-1,435$ & $-10.2 \%$ \\
\hline \multirow[t]{2}{*}{$\begin{array}{l}\text { Other law } \\
\text { offenses }\end{array}$} & Cases & 10,090 & 9,263 & 8,024 & 9,564 & 10,488 & 13,357 & 15,041 & 14,828 & 12,675 & 10,052 & 8,050 & 7,275 & 5,784 & 4,696 & $-1,088$ & $-18.8 \%$ \\
\hline & Persons & 8,036 & 7,473 & 6,382 & 7,492 & 8,522 & 11,282 & 12,944 & 12,673 & 10,724 & 8,386 & 6,737 & 6,067 & 5,148 & 4,163 & -985 & $-19.1 \%$ \\
\hline
\end{tabular}

Note: Source: Keisatsucho Keijikyoku Soshikihanzaitaisakubu Kokusaisosa Kanrikan "Rainichi Gaikokujin Hanzai no Kenkyo Jokyo (Heisei 23 Nen Zanteichi)", February 4 2012, p. 2, retrieved May 16, 2013 (http://www.npa.go.jp/sosikihanzai/kokusaisousa/kokusai/H23_Z_RAINICHI.pdf).

Table 4. Registration of Foreign Workers (Japan)

\begin{tabular}{|c|c|c|c|c|c|c|c|c|c|c|c|c|c|c|c|}
\hline Year & 1997 & 1998 & 1999 & 2000 & 2001 & 2002 & 2003 & 2004 & 2005 & 2006 & 2007 & 2008 & 2009 & 2010 & 2011 \\
\hline$\overline{\text { Numb }}$ & 113,96 & 114,753 & 115,038 & 120,484 & 130,440 & 141,285 & 157,247 & 179,966 & 198,380 & 222,929 & No data & 486,398 & 562,818 & 649,982 & 686,246 \\
\hline
\end{tabular}

Note: Source: Kosei Rodosho “Gaikokujin Koyojokyo no Todokedejokyo" and “Gaikokujin Koyojokyo Hokoku”, retrieved May 16, 2013 (http://www.mhlw.go.jp/stf/houdou/ 2r985200000117eu.html). 
in Japan and in South Korea? Do South Koreans also perceive threats posed by an influx of foreign workers? In particular, this question is regarding to the threat to public order and social stability and the threat of rising unemployment. How have they ultimately come to the decision to move toward accepting foreign workers? Next, we must consider the environment in which the perceptions have developed. The Japanese argument that foreign workers pose a risk to public order and social stability has not been found on any solid data. We must ask, are the Korean opinions also not informed by objective information, but by stereotypes held by South Koreans about foreign workers and the possible outcomes of an influx of foreign workers? Or is the orientation of these beliefs in accord with realistic social conditions? By answering these questions, we shall be able to see the factors governing the orientation of beliefs and opinions in the South Korean case.

Negative arguments have to be balanced against progressive arguments regarding the acceptance of foreign workers. In other words, even if in South Korea as in Japan, or even to a greater extent, had there also been even more strongly compelling arguments in favor of the acceptance of foreign workers, then the acceptance of foreign workers would proceed regardless of arguments to the contrary. Of course, even with arguments in favor of acceptance, the decisive influences are broadly divided between objective and subjective factors. If there were arguments even stronger than those in favor of the acceptance of foreign workers in South Korea, would these be explained according to objective conditions, or alternatively informed directly by a South Korean mentality that was divorced from objective conditions?

Assuming the ideological conditions are the same in both countries, policy decisions may change according to differences in politically and socially contingent structures. Therefore, how exactly have the various and respective discussions on the acceptance of foreign workers into both Japan and Korea developed in the context of these contingent political and social structures? What is the relationship between the differences in contingent structures and the differences in outcomes?

Below is a concrete observation of the reality of conditions in South Korea.

\section{OBJECTIVE CONDITIONS AND DEBATES REGARDING FOREIGN NATIONALS IN SOUTH KOREA}

First, let us examine the objective conditions that are easily observed.

Table 5 shows the change over time in the population of foreign nationals in South Korea. It is clear that the foreign population is increasing in South Korea much more rapidly than in Japan. This becomes strikingly apparent after the introduction of the "employment permit system" in 2003, indicating that the change in South Korea's policies toward foreign workers has contributed tangibly to the increase in the number of foreigners admitted into the country. However, the increase in the foreign population in South Korea is not a result of an increase in foreign workers alone. For example, an important supplementary factor being cited is a rapid increase in international marriages, which is evident in Table 6. In South Korea, either of these figures, relative to the entire population, is vastly larger than the corresponding figure for Japan, illustrating just how dramatic the rise in the foreign population in South Korea really is.

Therefore, what has been the impact of this increase in the foreign population on Korean society? The statistics in Table 7 reveal the number of illegal residents. This table shows a decrease in the number of illegal residents, which is another result of the change in policies regarding foreign workers. It has been South Korea's explicit policy to encourage the legalization of illegal migrant workers by actively bringing them under its "employment permit system", 
Table 5. Population of Foreign Nationals (South Korea)

\begin{tabular}{|c|c|c|c|c|c|c|c|c|c|c|c|c|c|c|c|c|c|c|c|}
\hline Year & 1992 & 1993 & 1994 & 1995 & 1996 & 1997 & 1998 & 1999 & 2000 & 2001 & 2002 & 2003 & 2004 & 2005 & 2006 & 2007 & 2008 & \multicolumn{2}{|l|}{2009} \\
\hline Total & 65,673 & 76,374 & 95,778 & 123,881 & 167,664 & 201,1861 & 182,788 & $8 \quad 206,895$ & 244,172 & 267,630 & 287,923 & 437,014 & 469,183 & 485,477 & 632,490 & 765,429 & 854,007 & 870,636 & 918,917 \\
\hline Male & 36,175 & 42,332 & 54,917 & 70,755 & 99,813 & $122,798 \quad 1$ & 107,980 & $0 \quad 121,135$ & 143,177 & 153,449 & 159,356 & 257,628 & 278,377 & 283,998 & 370,728 & 438,660 & 480,136 & 485,806 & 514,956 \\
\hline Female & 29,498 & 34,042 & 40,861 & 53,126 & 67,851 & $78,388 \quad 7$ & 74,808 & 85,760 & 100,995 & 114,181 & 128,567 & 179,386 & 190,806 & 201,479 & 261,762 & 326,769 & 373,871 & \multicolumn{2}{|c|}{$384,830 \quad 403,961$} \\
\hline \multicolumn{20}{|c|}{ Note: Source: Korean Statistical Information Service, retrieved May 16, 2013 (http://kosis.kr/). } \\
\hline \multicolumn{20}{|c|}{ Table 6. International Marriages (South Korea) } \\
\hline \multirow{2}{*}{\multicolumn{5}{|c|}{ Total }} & 2000 & \multicolumn{2}{|l|}{2001} & 2002 & 2003 & \multicolumn{2}{|c|}{2004} & 2005 & 2006 & \multicolumn{2}{|c|}{2007} & 2008 & 2009 & \multicolumn{2}{|c|}{2010} \\
\hline & & & & & 11,605 & \multicolumn{2}{|c|}{14,523} & 15,202 & 24,776 & \multicolumn{2}{|c|}{34,640} & 42,356 & 38,759 & \multicolumn{2}{|c|}{37,560} & 36,204 & 33,300 & \multicolumn{2}{|c|}{34,235} \\
\hline \multicolumn{5}{|c|}{ Korean men and foreign women } & 6,945 & \multicolumn{2}{|l|}{9,684} & 10,698 & 18,751 & \multicolumn{2}{|c|}{25,105} & 30,719 & 29,665 & \multicolumn{2}{|c|}{28,580} & 28,163 & 25,142 & \multicolumn{2}{|c|}{26,274} \\
\hline \multicolumn{5}{|c|}{ Chinese } & 3,566 & 6,977 & & 7,023 & 13,347 & 18,4 & & 20,582 & 14,566 & 14,4 & & 13,203 & 11,364 & & 623 \\
\hline Vietnas & mese & & & & 77 & 134 & & 474 & 1,402 & 2,46 & & 5,822 & 10,128 & 6,61 & & 8,282 & 7,249 & & 623 \\
\hline Filipin & & & & & 1,174 & 502 & & 838 & 928 & 947 & & 980 & 1,117 & 1,49 & & 1,857 & 1,643 & & 906 \\
\hline Japane & & & & & 819 & 701 & & 690 & 844 & 809 & & 883 & 1,045 & 1,20 & & 1,162 & 1,140 & & 193 \\
\hline Cambo & dian & & & & 1 & 2 & & 2 & 19 & 72 & & 157 & 394 & 1,80 & & 659 & 851 & & 205 \\
\hline Thai & & & & & 240 & 182 & & 327 & 345 & 324 & & 266 & 271 & 524 & & 633 & 496 & 43 & 38 \\
\hline Americ & & & & & 231 & 262 & & 267 & 322 & 341 & & 285 & 331 & 376 & & 344 & 416 & 4 & 88 \\
\hline Mongo & lian & & & & 64 & 118 & & 194 & 320 & 504 & & 561 & 594 & 745 & & 521 & 386 & 32 & 66 \\
\hline Others & & & & & 773 & 806 & & 883 & 1,224 & 1,15 & & 1,183 & 1,219 & 1,33 & & 1,502 & 1,597 & & 532 \\
\hline Korean & womer & 1 and fo & reign $\mathrm{m}$ & & 4,660 & 4,839 & & 4,504 & 6,025 & $9,53 !$ & & 11,637 & 9,094 & 8,98 & & 8,041 & 8,158 & & 961 \\
\hline Japane & & & & & 2,630 & 2,664 & & 2,032 & 2,250 & 3,118 & & 3,423 & 3,412 & 3,34 & & 2,743 & 2,422 & & 293 \\
\hline Chines & & & & & 210 & 222 & & 263 & 1,190 & 3,618 & & 5,037 & 2,589 & 2,48 & & 2,101 & 2,617 & & 090 \\
\hline Americ & & & & & 1,084 & 1,113 & & 1,204 & 1,222 & 1,33 & & 1,392 & 1,443 & 1,33 & & 1,347 & 1,312 & & 516 \\
\hline Canadi & & & & & 150 & 164 & & 172 & 219 & 227 & & 283 & 307 & 374 & & 371 & 332 & & 3 \\
\hline Austral & lian & & & & 78 & 78 & & 90 & 109 & 132 & & 101 & 137 & 158 & & 164 & 159 & & 8 \\
\hline British & & & & & 64 & 69 & & 86 & 88 & 120 & & 104 & 136 & 125 & & 144 & 166 & 1 & 4 \\
\hline Germa & & & & & 82 & 94 & & 81 & 94 & 109 & & 85 & 126 & 98 & & 115 & 110 & & 35 \\
\hline Pakista & & & & & 36 & 63 & & 126 & 130 & 100 & & 219 & 150 & 134 & & 117 & 104 & 10 & 2 \\
\hline Others & & & & & 326 & 372 & & 450 & 723 & 779 & & 993 & 794 & 922 & & 939 & 936 & & 050 \\
\hline
\end{tabular}

Note: Source: Korean Statistical Information Service, retrieved May 16, 2013 (http://kosis.kr/). 
Table 7. Illegal Residents (South Korea)

\begin{tabular}{llllll}
\hline & 2002 & 2003 & 2004 & 2005 & 2006 \\
\hline Total & 308,165 & 154,342 & 209,841 & 204,254 & 211,988 \\
Male & 194,177 & 98,775 & 135,271 & 130,965 & 137,848 \\
Female & 113,988 & 55,567 & 74,570 & 73,289 & 74,140 \\
\hline
\end{tabular}

Note: Source: E. Narajipyo, retrieved May 16, 2013 (http://www.index.go.kr/egams/index.jsp).

Table 8. Crimes Committed by Foreign Nationals (South Korea)

\begin{tabular}{|c|c|c|c|c|c|c|c|c|c|c|c|c|c|}
\hline & 1998 & 1999 & 2000 & 2001 & 2002 & 2003 & 2004 & 2005 & 2006 & 2007 & 2008 & 2009 & 2010 \\
\hline Total & 2,300 & 3,012 & 3,438 & 4,328 & 5,221 & 6,144 & 9,103 & 9,042 & 12,657 & 14,524 & 20,623 & 23,344 & 22,543 \\
\hline Fluctuation (\%) & - & 31 & 14.1 & 25.9 & 20.6 & 17.7 & 48.2 & -.7 & 40 & 14.8 & 42 & 11.6 & -3.4 \\
\hline Killing & 12 & 22 & 18 & 40 & 47 & 32 & 60 & 42 & 72 & 54 & 85 & 103 & 83 \\
\hline Robbery & 64 & 86 & 58 & 113 & 100 & 137 & 157 & 124 & 107 & 118 & 133 & 260 & 221 \\
\hline Rape & 14 & 11 & 17 & 34 & 41 & 49 & 52 & 62 & 68 & 114 & 114 & 126 & 156 \\
\hline Theft & 263 & 305 & 444 & 590 & 599 & 630 & 825 & 821 & 971 & 1,213 & 1,343 & 2,001 & 1,741 \\
\hline Violence & 623 & 870 & 1,174 & 1,380 & 1,865 & 2,071 & 2,424 & 1,919 & 2,483 & 3,369 & 4,940 & 5,322 & 5,885 \\
\hline Intellectual offense & 262 & 445 & 449 & 589 & 586 & 834 & 1,965 & 3,340 & 6,229 & 5,685 & 7,472 & 4,792 & 4,487 \\
\hline Sexual violence & 19 & 32 & 30 & 44 & 29 & 49 & 40 & 32 & 52 & 62 & 64 & 72 & 99 \\
\hline Drugs & 4 & 23 & 26 & 82 & 99 & 120 & 218 & 152 & 73 & 231 & 694 & 778 & 720 \\
\hline Others & 1,039 & 1,218 & 1,222 & 1,456 & 1,873 & 2,222 & 3,362 & 2,550 & 2,602 & 3,678 & 5,778 & 9,890 & 9,151 \\
\hline
\end{tabular}

Note: Source: E. Narajipyo, retrieved May 16, 2013 (http://www.index.go.kr/egams/index.jsp) 
and the data show that this doctrine has been very effective. Compared to the previous implementation of the permitting system, the employment turnover rate among foreign workers has been greatly reduced as a result of the proactive recognition of foreign workers as valid workers and granting them suitable positions. Thus, foreign workers now have a sense of security, and are able to continue working, which results in a decrease in job turnover, which at the same time results in a decrease in the number of unlawful residents.

However, conditions for foreign workers in South Korea are not entirely favorable. Table 8, which shows the national trends in crimes committed by foreign residents, illustrates a consistent upward trend, with the exception of 2010. In contrast, in Japan, despite an increase in the foreign population, there has been no corresponding increase in number of crimes committed by foreigners. Conditions in South Korea, with regard to this point, are worse than those in Japan. Admittedly, it is true that a rise in crime rates does not automatically mean that all of them are vicious in nature; however, in any case, this situation provides us with a large indicator of the current conditions in the two countries.

Regarding the economy, in particular the impact on the unemployment rate, Table 9 shows the changes over time in South Korea's unemployment rate. In particular, the unemployment rate is affected by trends in the economy and various other elements like in Japan (see Table 10); so identifying any direct correlation with the rise in foreign workers is difficult, even in South Korea. Of course, the influences at a micro level must be concerned. Nonetheless, it is prudent to note that it is impossible to assert that the increase in foreign workers has had any significant effect on South Korean employment conditions at the macro level ${ }^{3}$.

So how are these conditions understood in South Korea? First, it must be mentioned that there is evidence of opposition to the immigration of foreign workers in South Korea as well. For example, on March 11, 2011, the Chosun Ilbo, an influential Korean newspaper, reported the following:

There are 1.25 million foreign nationals now living in South Korea, legitimately or otherwise, making up $2.5 \%$ of the total population. Through the government's policy of multiculturalism (internationalization), which has been gaining momentum since 2005, supporting and making allowances for socially vulnerable foreigners has been increasingly recognized as "common sense" in South Korean society. On the other hand, more than a few groups and websites are openly opposed to foreigners. [Chōsen Nippō (The Chosun Ilbo) 2011]

As representatives of such organizations, the Chosun Ilbo cites the "Citizens' Alliance Against Foreign Workers"4, "Anti-Multiculturalism", the "Republic of Korea Patriotic Society", and the "Society of Victims of Pakistani and Bangladeshi

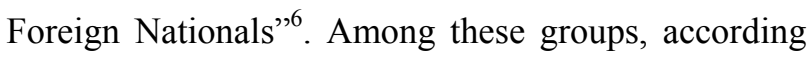
to the same newspaper, the "Citizens' Alliance Against Foreign Workers" has more than 6,000 members, while the other groups have enrolled between 3,000 and 5,000 members.

So why are these groups so opposed to the acceptance of foreign workers? Another article in the same Chosun Ilbo, summarizes the reasons behind these groups' opposition toward the admission of foreigners into the country, and insistence on immigration restrictions as being that "an increase in foreign workers will mean fewer jobs for Koreans, and their victimization by foreigner crime". As these two concerns are also among the chief rationales for opposing the acceptance of foreign workers in Japan, one can see that the same argument actually exists in South Korea as well.

As widely known, the South Korean proactive policy of accepting foreigners into South Korea that began under the administration of Roh Moo-hyun continues today under the administration of Lee Myung-bak. So why did arguments against the acceptance of foreign workers, which were influential 
Table 9. Unemployment Rates (South Korea)

\begin{tabular}{lllllllllllll}
\hline & 2000 & 2001 & 2002 & 2003 & 2004 & 2005 & 2006 & 2007 & 2008 & 2009 & 2010 & 2011 \\
\hline Total & 4.4 & 4 & 3.3 & 3.6 & 3.7 & 3.7 & 3.5 & 3.2 & 3.2 & 3.6 & 3.7 & 3.4 \\
$15-19$ & 14.5 & 14.4 & 12.1 & 13 & 14.1 & 12.5 & 10.4 & 9.3 & 10.2 & 12.2 & 11.9 & 10.8 \\
$20-29$ & 7.5 & 7.3 & 6.6 & 7.7 & 7.9 & 7.7 & 7.7 & 7.1 & 7 & 7.9 & 7.8 & 7.4 \\
$30-39$ & 3.6 & 3.2 & 2.9 & 3 & 3.1 & 3.3 & 3 & 3.2 & 3.1 & 3.6 & 3.5 & 3.4 \\
$40-49$ & 3.5 & 3 & 2 & 2.2 & 2.3 & 2.5 & 2.3 & 2 & 2.1 & 2.4 & 2.5 & 2.1 \\
$50-59$ & 3.2 & 2.8 & 1.9 & 2.2 & 2.3 & 2.5 & 2.2 & 2.1 & 2 & 2.5 & 2.5 & 2.1 \\
$60-$ & 1.5 & 1.2 & 1.1 & 1 & 1.2 & 1.3 & 1.4 & 1.4 & 1.2 & 1.6 & 2.8 & 2.6 \\
\hline
\end{tabular}

Note: Source: Korean Statistical Information Service, retrieved May 16, 2013 (http://kosis.kr/).

Table 10. Unemployment Rates (Japan)

\begin{tabular}{lllllllllllll}
\hline & 2000 & 2001 & 2002 & 2003 & 2004 & 2005 & 2006 & 2007 & 2008 & 2009 & 2010 & 2011 \\
\hline Total & 4.7 & 4.8 & 5.2 & 5.4 & 4.9 & 4.5 & 4.4 & 4 & 3.9 & 4.3 & 5.1 & 4.9 \\
$15-24$ & 8.2 & 9.6 & 10.3 & 10.2 & 10 & 8.2 & 8.1 & 8.8 & 7.3 & 7.9 & 9.1 & 8.3 \\
$25-34$ & 6 & 5.7 & 6.3 & 6.2 & 5.8 & 5.9 & 5.3 & 5.2 & 4.9 & 5.7 & 6.4 & 6.4 \\
$35-44$ & 3.1 & 3.4 & 3.8 & 4.5 & 3.9 & 3.7 & 3.6 & 3.3 & 3.6 & 4 & 4.6 & 4.2 \\
$45-54$ & 3.3 & 3.1 & 3.9 & 3.8 & 3.5 & 3.1 & 3.3 & 2.7 & 2.8 & 3.3 & 3.9 & 3.8 \\
$55-64$ & 5.5 & 5.5 & 5.6 & 5.9 & 4.9 & 4.2 & 4.6 & 3.3 & 3.7 & 3.6 & 4.8 & 4.8 \\
$65-$ & 2.1 & 2.3 & 2.1 & 2.7 & 2.3 & 1.8 & 2.1 & 2.3 & 1.9 & 1.8 & 2.8 & 3 \\
\hline
\end{tabular}

Note: Source: Statistics Japan "Rodoryokuchosa Choki Jikeiretsu deta", retrieved May 16, 2013 (http://www.stat.go.jp/data/ roudou/longtime/03roudou.htm).

in Japan, fail to gain traction to a similar degree in South Korea?

\section{DIFFERENCES IN POLITICALLY CONTINGENT STRUCTURES}

In any consideration of the differences in each country's acceptance of foreign workers, perhaps similar to the differences in public opinion, or even more influential, they are differences in politically contingent structures. It is a matter of fact that, any political system will reflect the various opinions of society, but these opinions do not necessarily inform (are reflected) political decisions. In other words, when considering various arguments surrounding the acceptance of foreign workers into both South Korea and Japan, we need to look at how those opinions are represented, or not, within the political systems of both countries.
To begin, let us take a look at the sorts of groups that call for the exclusion of foreign workers, considering them from a theoretical perspective. Broadly speaking, there are two distinct types of such groups. The first type is groups that propagate ethno-nationalist ideology. The membership of these people insists on the exclusion of foreign workers out of a perceived need to preserve the ethno-national identity of their own society. Usually, among organizations and individuals in this category, it is the predisposition to retain vestiges of cold war ideology. There is a tendency to back the so-called conservative political parties. This is due to the fact that in more progressive political parties, there is a tendency to advocate from class-based or cosmopolitan positions more than from nationalist ones, and the two are largely incompatible. For this first type of group, ethno-national identity trumps employment. Therefore, such groups will be much more likely to exercise 
vigilance against disruption of the cultural order by foreign workers.

In contrast, a second type of organization advocating the exclusion of foreign workers is comprised of those who do so not from the perspective of ethno-nationalism, but from that of employment. An obvious example of this type is labor unions. Many labor unions have a tendency of supporting what might be called progressive political parties. Most progressive parties still cling to a "socialist" ideology of one form or another and aim to realize conditions that value distribution over growth.

Next, let us think about those organizations that view the acceptance of foreign workers in a more positive light. On this point, the industry may be the party most actively interested in bringing in foreign workers. For industries both in Japan and South Korea, where wage levels are relatively high by both international and regional standards, the acceptance of foreign workers into the country means a reduction in wages, and therefore, supported by those paying the wages. In addition, given the aging population and the reduction of the working population, which are expected to continue in both Japan and Korea, the arrival of foreign workers is also of great importance for the industry to secure absolute labor capacity.

However, the business community does not hold a monopoly or support for the acceptance of foreign workers. We may think here of organizations that advocate for the better treatment of foreign workers, or from a cosmopolitan perspective, advocate for the improvement of labor conditions in developing countries. Needless to say, labor conditions in many developing countries are much worse than those of advanced countries, even putting wages aside, and to some degree, it is only natural for people to want to pull up roots and continue searching for more favorable working conditions. For those who embrace a cosmopolitan sense of values, to hinder labor migration for ethno-nationalist reasons or out of a "selfish" desire to maintain one's own wage levels represents a clear betrayal of ideals and therefore should be avoided. Hence, it is for their own ideological reasons that such individuals will advocate for the proactive acceptance of foreign workers.

Therefore, how are these different interests positioned in Japan and South Korea? Both countries have ethno-nationalist "citizen's groups" that ostracize foreign workers and foreign residents. In Japan, there is the well-known example of Zaitokukai ("Citizens Against Special Privilege of Zainichi”) ${ }^{7}$, though their membership, which (as it is listed in their public relations material) as of 2011 had only just crept over the 10,000 mark $^{8}$, which somewhat pales in comparison to that of the South Korea anti-immigrant groups mentioned earlier. Nonetheless, given the relative population sizes of Japan and South Korea, we should probably rather say that they are on a smaller scale than their South Korean counterparts.

However, there is a large difference in the relative influence of ethno-nationalist anti-foreigner groups in the two countries. In South Korea, such groups have an extremely limited influence. They rarely receive any coverage in the media, and when they do, such coverage is uniformly negative, even in the politically conservative media. Nor do any individuals connected with such groups hold any relationship to major political parties.

Compared to the South Korean case, the influence of ethno-nationalist anti-foreigner groups in Japan, is entirely different. For example, we can see stances similar to that of Zaitokukai taken by many Japanese politicians. In addition, in their anti-Korean activities, the group enjoys a certain relationship with the manga artist Yamano Sharin, who amongst other things designed the group's mascot character, and is the creator of Kenkanryū (Hating "the Korean Wave"), a popular manga, which by 2009 had sold 900,000 copies ${ }^{9}$. Also, Zaitokukai's spokesperson Makoto Sakurai has had various opportunities to get his message out directly, by way of such media vehicles as "Channel Sakura" on cable $\mathrm{TV}^{10}$. Known for the 
critical tone of its coverage of the South Korean economy, "Channel Sakura" regularly hosted such guests as Takaaki Mitsuhashi, who stood as a candidate for the Liberal Democratic Party (LDP) in the 2010 general election, and Kyoko Nakayama, who served under the Fukuda administration as State Minister in charge of Special Issues. The author does not mean to imply that these individuals necessarily have any direct connection to groups whose xenophobia stems from ethno-nationalism. Nonetheless, by looking at the picture, there is evidence of loose connections between this one major organization and established political parties like LDP and the Party for Japanese Kokoro, and to political circles above a certain level.

The point the author is making is that, while Japan's anti-immigrant groups enjoy relationships with influential politicians and individuals, those in Korea exist in a largely isolated state. Therefore, how are the labor unions situated, expecting that their opposition to immigration comes from a different angle? In this regard, the attitudes of labor unions toward the acceptance of foreign workers differ between the two countries. Japan's largest labor union organization, RENGO (The Japanese Trade Union Confederation) maintains a relatively clear position on this point.

Since its publication in 1988 (at which time it was a private sector organization known as Minkan Rengo) of "Views Regarding Premises and Criteria for the Acceptance of Foreign Workers," which stated that "acceptance of foreign workers shall be limited to those fields requiring expert knowledge, techniques, and skills, and who observe the principles of harmony with domestic employment and national consensus", RENGO has consistently maintained a more or less negative attitude toward any expansion in the acceptance of foreign workers [RENGO (Japanese Trade Union Confederation) 2012]. In contrast, the two principal labor organizations in Korea, the Federation of Korean Trade Unions (FKTU, also known as Inochong) ${ }^{11}$ and the Korean Confederation of Trade Unions (KCTU, also known as Nodong) ${ }^{12}$, are not expressly opposed to the acceptance of foreign workers. What is characteristic about attitudes toward foreign workers amongst South Korea's principal organizations is that they actively support those foreigners who are already resident in the country. In addition, in order to advocate for their better treatment, unions are actively engaged in recruiting them into the unions. In other words, where Japan's labor unions see foreign workers as a threat, and continue with restrictions; South Korean unions see them as comrades, and are working actively for their acceptance.

Relationships between labor unions and political parties also differ greatly between the two countries. In Japan, the fact is that RENGO's intimate relationship with the Democratic Party of Japan (DPJ) is widely known. On the other hand, in South Korea, labor unions have not necessarily enjoyed the smoothest of relationships with the country's two traditionally dominant parties. Both unions have a history of working toward autonomous political influence, and in fact, KCTU formed the Democratic Labor Party and maintained a certain number of seats in the national assembly. FKTU has achieved a certain degree of influence through its relationship to the current Minjoo Party of Korea, but it cannot be said that this relationship is necessarily assured ${ }^{13}$. What is clear in any case is that while, in Japan, labor unions enjoy a large window into the government's policy-making process, their influence in Korea remains marginal.

Next, let us turn to those organizations that support the acceptance of foreign workers. It is evident that the business communities of both countries actively support the acceptance of foreigners. But the orientation of their influence is quite different. With the recent emergence of the duopolistic political atmosphere polarized between the DPJ and the LDP, Japan's business community has been unable to 
maintain a clearly defined strategy, and as a result, there have been indications of its declining influence in the policy-making process. In particular, relations with the DPJ, the champions of "political leadership", can hardly be said to have been smooth, and some have said that this has prompted a grave sense of crisis in the business world. Conversely, in South Korea where politics have been divided between the conservative and progressive parties established following the country's democratization, the business community continues to maintain a close relationship with the conservative political parties associated with the current Saenuri Party.

Finally, let us inquire into the ideological basis of those groups that advocate an expansion in the acceptance of foreign workers. Activities by Japan's various groups are not very lively on this front. Of course, even in Japan, there are numerous groups that seek better treatment for foreign workers, but whereas many of these have long advocated for human rights and the improvement of labor conditions for foreign workers, this does not necessarily also mean that they have actively sought an expansion of their presence, or the legalization of illegal residents ${ }^{14}$.

In South Korea, the movement is in another direction entirely. Essentially, while the tendency in Japan for the "protection of human rights for foreign workers" to be tied up with an "expansion in the acceptance of foreigners" is extremely slight, in South Korea, the two tend to be bound up together. In South Korea, civil society organizations have been working actively since the 1990s to demand better treatment of foreign workers, a movement that has seen the participation of highly influential religious groups and labor unions ${ }^{15}$. It is a well-known fact that it was initiative to improve the human rights situation in South Korea that resulted in the move to rethink the previous "industrial trainee system", and create the subsequent "employment permit system" brought in under Roh Moo-hyun's administration. An emblematic outcome of this system was its legalization of illegal residents who had been in South Korea for less than three years prior to its implementation. In order to improve the human rights situation for foreign workers, it is necessary to be able to guarantee stable employment for a certain period of time. Because unskilled workers had already been accepted into South Korea as "trainees", a desire to improve their situation would necessarily have implied officially prohibiting them from menial labor. For exactly this reason, the movement to improve the treatment of foreign workers inevitably had no choice but to officially recognize the engagement of foreign workers in simple labor, and work in the direction of expansion. In addition, it must not be overlooked that in South Korea, these groups enjoy significant influence in the policy-making process. As South Korea's progressive camp undergoes repeated reorganizations, many of South Korea's civil society organizations have steadily come to occupy a position of importance.

\section{CONCLUSIONS}

In the final analysis, clearly, there are differences between the politically contingent structures of Japan and South Korea, as they interact with the issue of foreign workers. In Japan, xenophobic influences that have little political opportunity in South Korea have not only achieved some measures of influence through conservative political parties, but labor unions similarly opposed to the acceptance of foreign workers also enjoy significant influence. In contrast, xenophobic groups in South Korea possess almost no connection to policy-making processes, and the influence of labor unions remains peripheral. Labor unions in South Korea do not seem to be opposed to an expansion of acceptance of foreign workers.

While Japan continues to restrict foreign nationals, in Korea, there has been an opening of opportunities for forces that seek an expansion in the acceptance of immigrants. The influence of the business community 
in South Korea informs conservative political parties, while improvements in the treatment of foreigners from a human rights perspective, and the resulting influences of interests calling for the expansion of acceptance are reflected in progressive political parties. This has been structural. As a result, a structure has been realized where the two dominant political parties, conservative and progressive, are actively in favor of accepting foreign workers.

In contrast, Japan's long-term economic recession and the establishment of a new conservative-dominated two-party political system have resulted in a marked decline in the influence of the business community. And even as many human rights organizations actively seek better treatment for foreigners, paradoxically, many human rights organizations also have simultaneously come to oppose the further acceptance of unskilled workers.

One last point to be made is that there is a structure similar to the relationship with the political parties in the relationship with the mass media. While structures exist in Japan to facilitate anti-immigration messages being taken up in the mass media, in South Korea, it is reversed. Regardless of the fact that the situation surrounding foreign workers is not significantly different, it is the differences in politically and socially contingent structures that have caused Japan to maintain a cautious stance on the acceptance of foreign workers, and that have caused South Korea to move energetically toward acceptance.

So how were these types of differences in contingent structures brought about in the first place? In both countries, but especially in South Korea, the political situation since democratization and the conditions following the 1997 Asian financial crisis may be important in this regard.

\section{Notes}

* This paper is a revised version of the author's paper written in a domestic language according to the changing situation.
The original paper is as follows: Kan Kimura, "Nikkan no Iminseisaku wa Naze Kotonarunoka" (Why Immigration Policies Are Different Between Japan and South Korea)? Ajia Jiho, no. 494, March 2014.

1. Regarding changes to South Korean policies controlling foreign nationals see also the author's article "Gaikokujin sanseiken o sokushin suru 'Nashonaru Popyurizumu", ("National Populism" and the Promotion of Voting Rights for Foreign Nationals). In Imin to Seiji (Immigration and Politics), edited by Y. Kawahara, Y. Shimada, and Y. Tamada. Shōwadō, 2011.

2. Representative examples include Nakamura, J., H. Naitō, R. Kambayashi, D. Kawaguchi, and T. Machikita. 2009. "Nihon no gaikokujin rōdōryoku" (The Foreign Workforce in Japan). Nihon Keizai Shinbun Shuppansha; and Ono, G. 2007. "Gaikokujin rōdōsha ukeire wa Nihon o dame ni suru" (Accepting Foreign Workers Spoils Japan). Yōsensha.

3. For a more detailed analysis, see Kim, C.-H. 2009. "Chosungnyon oeguk illyok yuip ui kyongjejok yonghyang punsok" (The Economic Impacts of Low-Skilled Immigrants in Korea). Korea Development Institute; and Yu, K.-J. 2009. "Oeguk illyok ui hyonhwang kwa chongch'aek kwaje" (Status of Foreign Workers and Policy Challenges). KDI.

4. Citizens' Alliance Against Foreign Workers. Retrieved February 29, 2012 (http://www.njustice.org/).

5. The Republic of Korea Patriotic Society. Retrieved February 29, 2012 (http://cafe.naver.com/riseupkorea).

6. Society of Victims of Pakistani and Bangladeshi Foreign Nationals. Retrieved February 29, 2012 (http://cafe.daum. net/leavingpakistan).

7. Citizens Against Special Privilege of Zainichi (Zaitokukai). Retrieved February 29, 2012 (http://www.zaitokukai.info).

8. The same group's website cites an enrollment of 11,230 members. Zaitokukai, Kai'in bunpu-zu (Membership Map). Retrieved February 29, 2012 (http://www.zaitokukai.info/ modules/about/zai/membermap.html).

9. This is not to say that Yamano Sharin agrees entirely with Zaitokukai or others similarly involved in so-called Kenkan, or anti-Korean movements. For instance, see Nikkan, C. Manga kenkan ryū no sakusha Yamano Sharin ga Odaiba no "kenkan demo" ni kubi o kashigeru riyū to wa (Why Did Yamano Sharin, Creator of Hating "the Korean Wave", Shake His Head at the Anti-Korean Protest in Odaiba)? Retrieved February 29, 2012 (http://www.cyzo.com/2011/ 08/post_8156.html).

10. Channel Sakura. Retrieved (http://www.ch-sakura.jp/). As an independent cable television station, the channel also maintained its own 24-hour broadcast until 2008, but owing to business difficulties, currently only distributes its 
programs to other networks.

11. Hanguk Nodong Johap Chongyeonmaeng (Federation of Korean Trade Unions). Retrieved February 29, 2012 (http:// www.inochong.org/).

12. Jeon-guk Minju Nodong Johap Chongyeonmaeng (Korean Confederation of Trade Unions). Retrieved February 29, 2012 (http://www.nodong.org/).

13. FKTU formally participates in South Korea's Democratic United Party, which was formed in December 2011, and is represented by one of their members on the party's central committee. However, given that this same Federation, with a view to securing independent influence, formed the Green Social Democratic Party in 2004 jointly with the South Korean Social Democratic Party, and backed Lee Myung-bak, the candidate of the conservative Grand National Party, in the 2007 presidential election. One cannot say that its relationship with the progressive influence associated with the Democratic United Party is secure. FKTU. Retrieved February 29, 2012 (http://www. inochong.org/).

14. A typical example of this attitude is seen in the Social Democratic Party (SDP). Among the party's central tenets, in direct contrast to its advocating better treatment of foreign workers, is its broad opposition to the acceptance of unskilled labor. The Zentoitsu Workers' Union, one of the SDP's main organizational backers, takes a similar stance.

15. For the particulars, refer to Sano, K. 2010. "Kankoku ni okeru gaikokujin rōdōsha shien shisutemu: intabyū chōsa o chūshin ni” (Foreign Worker Support System in South Korea: An Interview-Based Study). Shōgaku Ronshū (Essays in Commerce) 79(3). December 2010, Fukushima University. See also the author's article "Gaikokujin sanseiken o sokushin suru 'Nashonaru Popyurizumu", ("National Populism" and the Promotion of Voting Rights for Foreign Nationals).

\section{References}

Chōsen Nippō (The Chosun Ilbo). 2011. Kankoku de takamaru gaikokjin rōdōsha e no hanpatsu (Rising Backlash Against Foreign Workers in Korea). Retrieved March 11, 2011 (http://www.chosunonline.com/site/data/html_dir/2011/03/ 31/2011033163050.html).

Fujiwara, N. 2010. "Kankoku no kokuseki-hō kaisei: Gentei-tekina jūkokuseki no yōnin" (Revisions to South Korea's Nationality Act: Limited Approval of Multiple Citizenship). Gaikoku no Hōritsu (Foreign Law) 245, September 2010.

Kim, C.-H. 2009. "Chosungnyon oeguk illyok yuip ui kyongjejok yonghyang punsok" (The Economic Impacts of Low-Skilled Immigrants in Korea). Korea Development Institute.

Kimura, K. 2011. "Gaikokujin sanseiken o sokushin suru 'Nashonaru Popyurizumu"” ("National Populism" and the Promotion of Voting Rights for Foreign Nationals). In Imin to Seiji (Immigration and Politics), edited by Y. Kawahara, Y. Shimada, and Y. Tamada. Shōwadō, 2011.

Koyō Seisaku Kenkyūkai (Employment Policy Research Group). 2010. Koyō Seisaku Kenkyūkai Hōkokusho (An) (Draft Employment Policy Research Group Report). Retrieved February 29, 2012 (http://www.mhlw.go.jp/shin gi/2007/11/dl/s1128-15a.pdf).

Naikakufu Daijin Kanbō Seifu Kōhōshitsu (Cabinet Secretariat, Cabinet Public Relations Office). 2004. Gaikokujin rōdōsha no ukeire ni kan suru yoron chōsa (Public Opinion Poll on the Acceptance of Foreign Workers). Retrieved February 29, 2012 (http://www8.cao.go.jp/survey/h16/h16-foreignerwor ker/index.html).

Nikkan, C. Manga kenkan ryū no sakusha Yamano Sharin ga Odaiba no "kenkan demo" ni kubi o kashigeru riyū to wa (Why Did Yamano Sharin, Creator of Hating "the Korean Wave", Shake His Head at the Anti-Korean Protest in Odaiba)? Retrieved February 29, 2012 (http://www.cyzo. com/2011/08/post_8156.html).

RENGO (Japanese Trade Union Confederation). 2012. Rengō no gaikokujin rōdōsha mondai ni kan suru tōmen no kangaekata (RENGO's View on the Issue of Foreign Workers). Retrieved February 29, 2012 (http://www. jtuc-rengo.or.jp/roudou/gaikokujin/kangaekata.html).

Sano, K. 2010. "Kankoku ni okeru gaikokujin rōdōsha shien shisutemu: intabyū chōsa o chūshin ni" (Foreign Worker Support System in South Korea: An Interview-Based Study). Shōgaku Ronshū (Essays in Commerce) 79(3). December 2010, Fukushima University.

The Dong-A Ilbo (East Asian Daily News). 2011. "Gaikokujin kōka" de jinkō 45 man'in zōka (Population Increase of 450,000 Through "Foreigner Effect"). Retrieved February 29, 2012 (http://japan.donga.com/srv/service.php3?bicode= 020000\&biid=2010040662838).

Yu, K.-J. 2009. “Oeguk illyok ui hyonhwang kwa chongch'aek kwaje" (Status of Foreign Workers and Policy Challenges). Korea Development Institute.

\section{Bio}

Kan Kimura, Ph.D., professor, Graduate School of International Cooperation Studies, Kobe University, Kobe, Japan; research fields: Korean studies and comparative politics. 